\title{
Pengaruh Sifat Fisik Tanah terhadap Hama Simphylid Pada tanaman Nanas (Ananas comosus (L.) Merr) di PT. Great Giant Pineapple Terbanggi Besar Lampung Tengah
}

\section{Effect of Soil Physical Properties Against Pests Symphilid In plants Pineapple (Ananas comosus (L.) Merr) in PT. Great Giant Pineapple Terbanggi Besar Central Lampung}

\author{
Sandi Aji ${ }^{1}$, Afandi ${ }^{2}$, Lestari Wibowo ${ }^{2}$, K.E.S. Manik ${ }^{2}$ \\ 1. Mahasiswa ${ }^{2}$. Dosen Jurusan Agroteknologi Fakuktas Pertanian Universitas Lampung \\ Jln. Prof, Soemantri Brojonegoro, No. 1, Bandar Lampung , 35145. \\ Korespondensi: Sandyajisp@gmail.com
}

\begin{abstract}
This research was conducted in the planting area of pineapple (Ananas comosus) PT. GGP Terbanggi Besar Central Lampung indicated attacked by pests simphylid in March 2014 until May 2014. Analysis of soil physical properties carried out in the Laboratory of Soil Science, Department of Agrotechnology, Faculty of Agriculture, University of Lampung. The method used in this study is a survey method. Soil sampling conducted at three locations indicated simphylid pests. Soil sampling done at some point and some depth. Results from this research that pest symphilid most numerous in one location with a number of acquisition 172 tail where the location of the physical properties of good land which the density value of the content is low, the total pore low, macropores and high hardness low ground, allowing sinphylid be able to live and thrive. While at the location of two and three with the condition density value of the content is high, the total pore high, macropores low, and violence high soil pests simphylid not so much discovered as simphylid can not multiply and survive on the physical condition of poor soil
\end{abstract}

Keywords: Pineapple, Symphilid, and physical properties of soil

Diterima: 11-08-2015: disetujui 23-10-2015

\section{PENDAHULUAN}

Nanas adalah komoditas hortikultura yang sangat potensial untuk dikembangkan di dunia.Nanas merupakan buah terpenting kedua setelahb uahpisang, produksinya mencapai $20 \%$ dari produksi buah tropika dunia.Nanas juga sangat berperan dalam bidang ekonomi karena nanas mendominasi perdagangan buah tropika dunia.Produksi nanas di Indonesia padatahun 2013 mencapai1.837.159 ton, sedangkan untuk produksi nanas di Provinsi Lampung pada tahun 2013 mencapai 722.620 ton (BPS, 2014).

PT. GGP menjadikan Provinsi Lampung sebagai provinsi dengan produksi buah nanas tertinggi di Indonesia.Namun, dibalik potensi budidaya yang menjanjikan keuntungan besar, terdapat 

permasalahan dalam budidaya nanas yaitu Organisme Pengganggu Tanaman (OPT). Salah satu OPT pada tanaman nanas adalah hama simphylid.

Symphylid menjadi hama penting pada tanaman nanas di PT. GGP karena serangannya dapat menyebabkan kerusakan pada akar nanas dan berakibat pada terganggunya penyerapan unsur hara dan air di dalam tanah. Tanaman yang terserang symphylid memiliki gejala visual daun tanaman berwarna merah, warna yang ditunjukan berbeda dengan jenis nanas yang daunnya memang berwarna merah. Pada tahap serangan lanjut, gejala merah yang muncul diikuti dengan mengecilnya lebar daun (daun menjadi kurus) dan tanaman menjadi kerdil. Akar tanaman yang terserang simphylid akan mengalami gejala witches broom (sapu setan) yaitu ujung akar terpotong, menumpul, dan akar-akar serabut tidak ada lagi. Biasanya pada akar yang menumpul akan tumbuh cabangakar yang baru dan pada akar yang menumpul tersebut terdapat lubang-lubang atau luka. Tanaman yang terserang simphylid jarang sekali yang ditemukan sampai mengalami kematian. Kebanyakan tanaman dapat tetap hidup tetapi produktivitas dan kualitasnya menurun.

\section{METODE}

Penelitian ini dilakukan di di areal pertanaman nanas (Ananas comosus) PT. GGP Terbanggi Besar Lampung Tengah yang terindikasi terserang oleh hama simphylid pada bulan Maret 2014 sampai Mei 2014. Analisis sifat fisik tanah dilakukan di Laboratorium Ilmu Tanah, Jurusan Agroteknologi, Fakultas Pertanian Universitas Lampung. Metode yang digunakan pada penelitian ini adalah metode survei. Pengambilan sampel tanah dilakukan pada tiga lokasi yang terindikasi serangan hama simphylid. Pengambilan sampel tanah dilakukan pada beberapa titik dan beberapa kedalaman. Analisis data dilakukan dengan membandingkan data sifat fisik yang diperoleh dengan sifat fisik tanah yang diterapkan untuk tanaman nanas.

Pengambilan contoh tanah dilakukan dengan menggunakan ring sampel pada kedalaman 0-20 dan 20-40 cm. Pengambilan sampel tanah dengan ring sampel digunakan untuk mengetahui sifat-sifat fisik tanah seperti kerapatan isi (bulk density). Variabel yang damati yaitu Kerapatan Isi (Bulk Density), Pori makro, pori total, jumlah simphylid, panjang akar, kekerasan tanah..

\section{HASIL DAN PEMBAHASAN}

Setelah dilakukan pengangkatan perangkap dari dalam tanah didapati jumlah simphylid yang diperoleh pada lokasi satu hanya 1 ekor, dan 15 ekor simphylid sehingga pada lokasi 1 didapati 16 ekor simphylid (tabel 1). Pada lokasi lain tidak terdapat simphylid dikarenakan pada saat pengambilan perangkap, perangkap tersebut dalam keadaan terendam oleh air sehingga tidak terdapat satupun simphylid didalamnya.

Tabel 1. Perolehan Jumlah Simphylid Minggu Pertama pada Lahan Pertanaman Nanas Terbanggi Besar, Lampung Tengah.

\begin{tabular}{ccccccccc}
\hline \multirow{2}{*}{ Lokasi } & \multicolumn{9}{c}{ Ulangan dan Jumlah Simphylid } & \multirow{2}{*}{ Total } & \multirow{2}{*}{ Rata Rata } \\
\cline { 2 - 5 } & $\mathrm{U} 1$ & $\mathrm{U} 2$ & $\mathrm{U} 3$ & $\mathrm{U} 4$ & 0 & 16 & 3,2 \\
2 & 15 & 1 & 0 & 0 & 0 & & \\
3 & 0 & 0 & 0 & 0 & 0 & & \\
\hline
\end{tabular}


Pengangkatan perangkap yang kedua jumlah simphylid yang didapat semakin meningkat, pada lokasi petama jumlah total dari lima perangkap yang dipasang terdapat 156 ekor simphylid, pada lokasi kedua didapati jumlah simphylid sebanyak 110 ekor, dan lokasi ketiga didapati jumlah symphylid sebanyak 96 ekor (tabel 2). Maka jumlah simphylid paling banyak terdapat pada lokasi satu dan jumlah simphylid paling rendah terdapat pada lokasi ketiga.

Tabel 2. Perolehan Jumlah Simphylid Minggu Kedua pada Lahan Pertanaman Nanas Terbanggi Besar, Lampung Tengah.

\begin{tabular}{ccccccccc}
\hline \multirow{2}{*}{ Lokasi } & \multicolumn{4}{c}{ Ulangan dan Jumlah Simphylid } & \multicolumn{2}{c}{ Total } & \multirow{2}{*}{ Rata Rata } \\
\cline { 2 - 5 } & U1 & U2 & U3 & U4 & U5 & & 31,2 \\
2 & 27 & 38 & 35 & 21 & 35 & 156 & 22 \\
3 & 27 & 23 & 15 & 38 & 7 & 110 & 19,2 \\
\hline
\end{tabular}

Pengukuran panjang akar dapat dilihat pada (Tabel 3) dapat diketahui bahwa tanaman yang memiliki akar paling panjang tedapat pada sampel tanaman pada lokasi ketiga yaitu 40, 35, dan $38 \mathrm{~cm}$ dengan rata rata panjang akar 37,67 $\mathrm{cm}$ digolongkan sebagai akar tanaman sehat, kemudian pada lokasi empat dengan panjang akar tanaman nanas 10,5, dan $7 \mathrm{~cm}$, dengan rata-rata panjang akar 7,33 $\mathrm{cm}$ maka dikategorikan sebagai tanaman dengan tingkat serangan sangat berat, lokasi kedua dengan panjang akar 0,5 , dan $0 \mathrm{~cm}$ dengan rata-rata panjang akar 1,67 cm maka dikategorikan sebagai tanaman dengan tingkat serangan sangat berat dan lokasi satu dengan panjang akar 0,5 , dan $0 \mathrm{~cm}$ dengan rata-rata panjang akar 1,33 cm maka dikategorikan sebagai tanaman dengan tingkat serangan sangat berat. Setelah data terkumpul maka dilakukan uji korelasi dengan jumlah simphylid.

Tabel 3. Panjang Akar Tanaman Nanas pada Lahan Pertanaman Nanas Terbanggi Besar, Lampung Tengah.

\begin{tabular}{|c|c|c|c|c|c|}
\hline \multirow{2}{*}{ Lokasi } & \multicolumn{3}{|c|}{ Panjang akar $(\mathrm{cm})$} & \multirow{2}{*}{ Rata rata } & \multirow{2}{*}{ Tingkat Serangan } \\
\hline & U1 & $\mathrm{U} 2$ & U3 & & \\
\hline 1 & 0 & 0 & 4 & 1,33 & Sangat Berat \\
\hline 2 & 0 & 5 & 0 & 1,67 & Sangat Berat \\
\hline 3 & 40 & 35 & 38 & 37,67 & Sehat \\
\hline
\end{tabular}

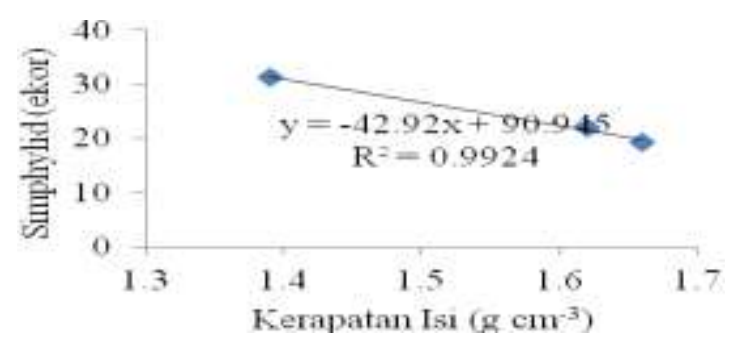

Gambar 1. Grafik Korelasi Linear Kerapatan Isi dan Jumlah Simphylid pada Kedalaman 0-20 cm

Hasil uji korelasi kerapatan isi dan jumlah simphylid pada kedalaman 0-20 cm (Gambar 1) menunjukan bahwa kerapatan isi memiliki korelasi negatif dengan jumlah simphylid. Namun hasil uji korelasi linear pada kerapatn isi dan jumlah simphylid pada kedalaman 20-40 cm (Gambar 2) memiliki korelasi yang positif dengan tingkat keeratan hubungan yang kuat dengan nilai $r=0,5835$. Hasil dari korelasi kerapatan isi dan jumlah simphylid menunjukan bahwa semakin tinggi nilai kerapatan isi maka semakin banyak jumlah simphylid pada lokasi tersebut. 
Sandi Aji dkk: Pengaruh Sifat Fisik Tanah Terhadap Hama Simphylid Pada tanaman Nanas....

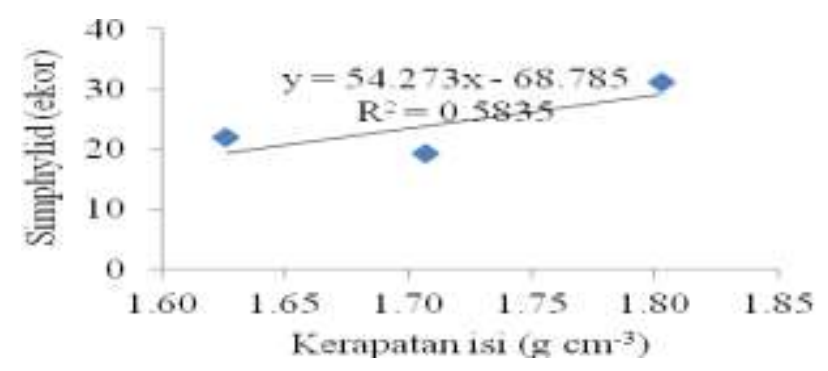

Gambar 2. Grafik Korelasi Linear Kerapatan Isi dan Jumlah Simphylid pada Kedalaman 20-40 cm

Hasil uji korelasi pori total dan jumlah simphylid pada kedalaman 0-20 (Gambar 3) menunjukan bahwa kerapatan isi memiliki korelasi positif dengan jumlah simphylid dengan nilai dengan nilai $r=0,7178$. Namun hasil uji korelasi linear pada kedalaman 20-40 cm (Gambar 4) memiliki korelasi yang negatif. Hasil dari korelasi pori total dan jumlah simphylid menunjukan bahwa semakin tinggi nilai pori total maka semakin banyak jumlah simphylid pada lokasi tersebut.

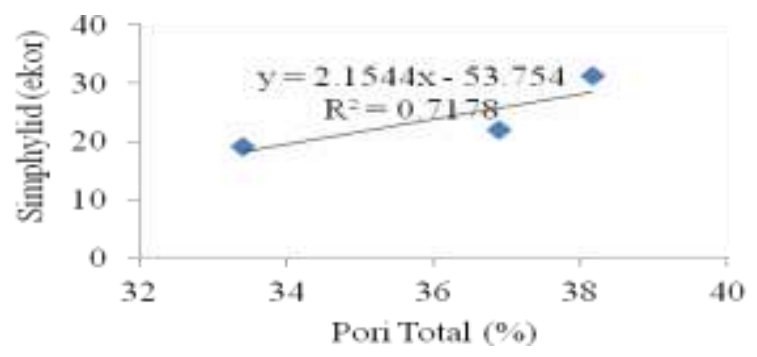

Gambar 3. Grafik Korelasi Linear Pori Total Tanan dan Simphylid pada Kedalaman 0-20 cm

Hasil uji korelasi pori makro dan jumlah simphylid pada kedalaman 0-20 (Gambar 4) menunjukan bahwa pori makro memiliki korelasi negatif dengan jumlah simphylid. Namun hasil uji korelasi linear pada kedalaman 20-40 cm (Gambar 6) memiliki korelasi yang positif dengan nilai $\mathrm{r}=0,309$. Hasil dari korelasi pori makro dan jumlah simphylid menunjukan bahwa semakin tinggi nilai pori makro maka semakin banyak jumlah simphylid pada lokasi tersebut karena semakin tinggi nilai pori makro tersebut maka simphylid dapat bergerak bebas di dalam tanah sehingga memungkinkan simphyid dapat berkembang dan bertahan hidup didalam tanah.

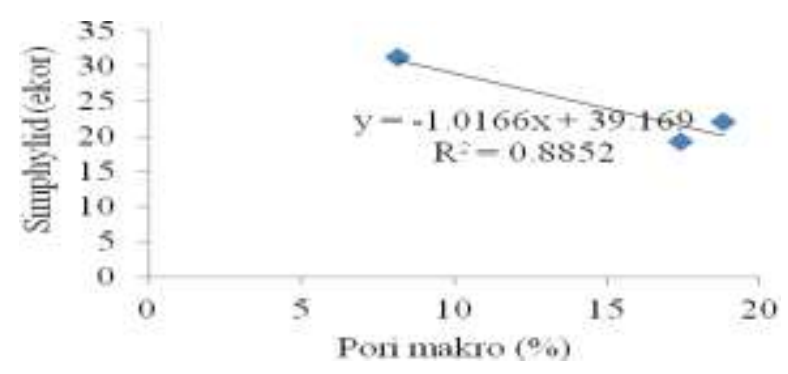

Gambar 4. Grafik Korelasi Linear \% Pori Makro dan Jumlah Simphylid pada Kedalaman 0-20 cm

Hubungan antara kekerasan tanah tanah terhadap jumlah simphylid dapat dilihat melalui uji korelasi sederhana. Hasil uji korelasi kekerasan tanah dan jumlah simphylid pada kedalaman $10 \mathrm{~cm}$ (Gambar 5) menunjukan bahwa kekerasan tanah pada kedalaman $10 \mathrm{~cm}$ memiliki korelasi negatif 
dengan jumlah simphylid dengan nilai dengan nilai $r=0,7485$, pada kedalaman $20 \mathrm{~cm}$ (Gambar 5) memiliki korelasi yang negatif dengan nilai $r=0,8685$, pada kedalaman $30 \mathrm{~cm}$ (Gambar 6) memiliki korelasi yang negatif dengan nilai $r=0,8263$ dan pada kedalaman $40 \mathrm{~cm}$ (Gambar 7) memiliki korelasi yang negatif dengan nilai $r=0,9503$. Hasil dari korelasi kekerasan tanah dan jumlah simphylid pada kedalaman $40 \mathrm{~cm}$, menunjukan bahwa peningkatan kekerasan tanah mengakibatkan peningkatan jumlah simphylid. Secara teori hal ini kurang sesuai, seharusnya peningkatan kekerasan tanah akan mengakibatkan penurunan perolehan jumlah simphylid atau sebaliknya.

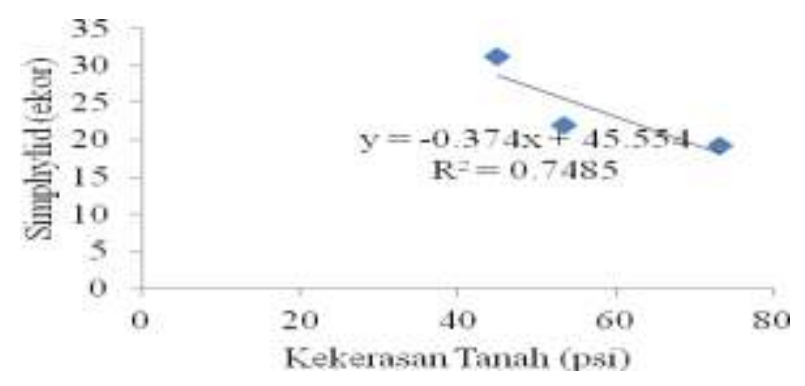

Gambar 5. Grafik korelasi linear kekerasan tanah dan jumlah simphylid pada kedalaman $10 \mathrm{~cm}$

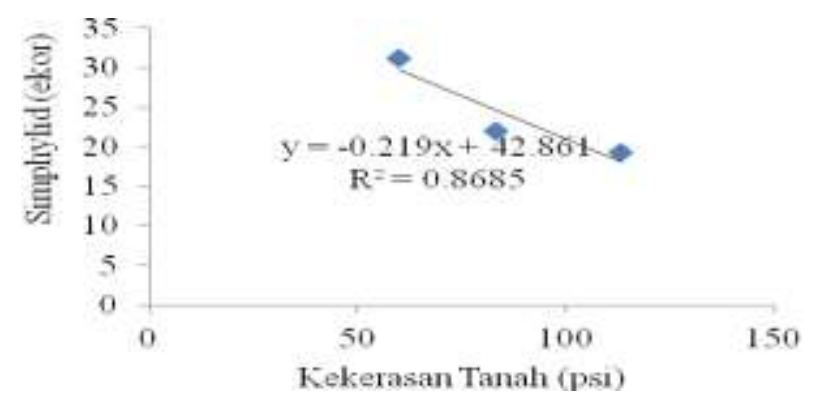

Gambar 6. Grafik korelasi linear kekerasan tanah dan jumlah simphylid pada kedalaman $20 \mathrm{~cm}$

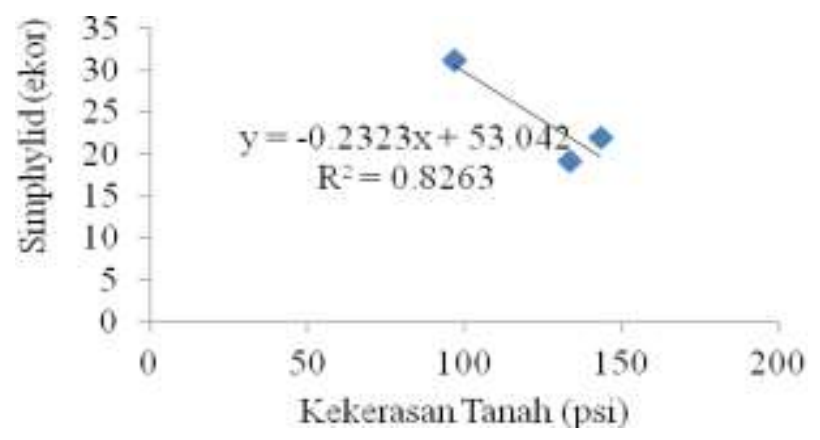

Gambar 7. Grafik korelasi linear kekerasan tanah dan jumlah simphylid pada kedalaman $30 \mathrm{~cm}$

Hasil survei mengenai keberadaan atau populasi simphylid yang dilakukan pada lokasi 45 dengan titik pengambilan lokasi pemasangan perangkap yang berbeda menunjukan populasi yang terhitung juga berbeda-beda. Lokasi terbanyak ditemukan simphylid terdapat pada lokasi satu dengan perolehan 16 ekor pada minggu pertaman dan 159 ekor pada minggu kedua. Sedangkan hasil perolehan perangkap paling sedikit ditemukan pada lokasi tiga yaitu dengan jumlah perolehan 110 ekor pada minggu kedua. 
Simphylid merupakan salah satu jenis mesofauna dalam tanah yang sebagian dikenal sebagai hama, dan perombak bahan organik (Alphonsine, 2011). Syimpilid memakan akar atau bagian tanaman di dalam tanah yang menyebabkan kehilangan hasil. Gejala pada daun tanaman nanas yang terserang simphyilid terlihat dari warna daun yang menjadi kuning hingga kemerahan kemudian masa akar manjadi lebih rendah dan pada akhirnya akan menyebabkan tanaman mati karena terganggunya proses penyerapan nutrisi tanaman. Simphylid cenderung ditemukan pada tanah dengan irigasi yang lebih berat dan tanah yang memiliki kandungan liat lebih banyak. Simphylid bergerak vertikal di dalam tanah, simphylid menjadi hama pada pertanaman nanas dengan manajemen tanah baik, pengolahan tanah yang baik, dan kompaksi tanah yang rendah (Umble et al., 2006). Jika lingkungan tanah menguntungkan, symphilid dapat bermigrasi dari permukaan tanah sampai kedalaman lebih dari 3 meter. Waktu migrasi vertikal disebabkan oleh interaksi antara kelembaban, suhu, dan makanan (Edwards, 1959).

Berdasarkan tabel 4 dan 5 nilai kerapatan isi pada penelitian ini sejalan dengan ruang pori total tanah, pada tanah yang memiliki nilai kerapatan isi tinggi, memiliki nilai pori total yang rendah, demikian juga sebaliknya. Hal ini sesuai dengan pendapat Soepardi (1983) bahwa, kerapatan isi tanah berbanding terbalik ruang pori total. Porositas tanah didefinisikan sebagai persentase volume tanah yang ditempati oleh air dan udara (Buckman dan Brady, 1982). Udara dan air keluar masuk melewati ruang pori tersebut. Menurul Hillel (1980), porositas atau pori total tanah adalah bagian yang tidak berisi bahan padatan tanah tetapi terisi oleh udara air. Pori tanah dibedakan menjadi pori kasar dan pori halus. Pori kasar berisi udara dan air gravitasi, yaitu air yang mudah hilang karena gaya gravitasi, sedangkan pori halus berisi udara dan air kapiler.

Ruang pori total tanah juga berperan dalam menahan air tanah, dengan ruang pori yang besar maka akan memiliki cukup ruang untuk menyimpan air. Tanah dengan total ruang pori yang besar biasanya didominasi dengan tanah oleh tekstur halus dan memiliki kandungan bahan organik yang tinggi. Tanah dengan tekstur liat memiliki porositas total (jumlah pori mikro + pori makro) yang lebih tinggi dari pada tanah dengan tekstur pasir (Hardjowigeno, 2003). Jika dilihat dari hasil pengamatan tanah di lokasi 45F memiliki ruang pori total kurang dari $60 \%$ pada setiap kedalamannya.Ketiaka poripori tanah besar dan sangat efisien dalam lalu lintas air dan udara, tetapi persentase volume yang ditempati pori-pori kecil, sehingga dalam kapasitas memegang air rendah. Pengolahan tanah dapat merubah persen pori makro yang menjadi lebih banyak dari pada pori mikro. Pori makro merupakan tempat air yang tidak dapat ditahan oleh tanah atau air gravitasi yang bertujuan untuk drainase dan pertukaran udara.

Tabel 4. Hubungan Tingkat Keparahan Serangan Hama Simphylid Terhadap Sifat Fisik Tanah.

\begin{tabular}{|c|c|c|c|c|c|c|c|}
\hline \multirow{3}{*}{ Lokasi } & \multirow{3}{*}{$\begin{array}{c}\text { Tingkat } \\
\text { kepararahan akar }\end{array}$} & \multicolumn{6}{|c|}{ Sifat Fisik Tanah } \\
\hline & & \multicolumn{2}{|c|}{ Kerapatan Isi } & \multicolumn{2}{|c|}{ Pori Total } & \multicolumn{2}{|c|}{ Pori Makro } \\
\hline & & $0-20$ & $20-40$ & $0-20$ & $20-40$ & $0-20$ & $20-40$ \\
\hline 1 & $(++++)$ & 1,39 & 1,8 & 38,2 & 29,91 & 8,13 & 18,2 \\
\hline 2 & $(++++)$ & 1,62 & 1,63 & 36,9 & 38,37 & 18,82 & 19,9 \\
\hline 3 & $(+)$ & 1,66 & 1,71 & 33,4 & 34,83 & 17,42 & 9,89 \\
\hline Keterangan: & $\begin{array}{c}(+) \\
(++++)\end{array}$ & angat Berat & $\begin{array}{l}\text { at keru } \\
\text { tingka }\end{array}$ & usaka & $\begin{array}{l}25 \% \\
\operatorname{ar} 75-1\end{array}$ & & \\
\hline
\end{tabular}

Berdasarkan tabel 4 terdapat korelasi antara jumlah populasi atau keberadaan simphylid dengan sifat fisik tanah yang baik seperti ruang pori tinggi, serta aerasi yang baik sehingga memungkinkan simphylid keluar masuk tanah dan mudah bergerak ketika lingkungan tidak 
mendukung. Simphylid tidak ditemukan atau tidak menjadi masalah bagi tanaman nanas pada kondisi tanah yang basah, sedangkan pada tanah yang kering simphylid menjadi hama yang menjadi permasalahan serius untuk tanaman nanas di PT. GGP. Berdasarkan pengamatan yang telah dilakukan, pengangkatan perangkap pada saat kondisi tanah dalam keadaan tergenang hama simphylid tidak banyak ditemukan, sedangkan pada lokasi yang sama ketika kondisi tanah kering hama simphylid banyak ditemukan. Hal ini membuktikan bahwa pada kondisi tanah atau lingkungan dapat mempengaruhi populasi hama simphylid.

\section{KESIMPULAN}

Berdasarkan pengamatan yang telah dilakukan maka dapat disimpulkan bahwa hama simphylid paling banyak terdapat pada lokasi satu dengan jumlah perolehan 172 ekor dimana pada lokasi satu memeiliki sifat fisik tanah yang baik yaitu dengan nilai kerapatan isi yang rendah, pori total yang rendah, pori makro yang tinggi dan kekerasan tanah yang rendah, sehingga memungkinkan sinphylid dapat hidup dan berkembang dengan baik. Sedangkan pada lokasi dua dan tiga dengan kondisi nilai kerapatan isi yang tinggi, pori total yang tinggi, pori makro yang rendah, dan kekerasan tanah yang tinggi hama simphylid tidak terlalu banyak ditemukan karena simphylid tidak dapat berkembang biak dan bertahan hidup pada kondisi fisik tanah yang buruk.

\section{DAFTAR PUSTAKA}

Alphonsine, P. 2010. A Bait and Trap Method for Sampling Symphylid Populations in Pineapple. $7^{\text {th }}$ International Pineapple Symposium.

Biro Pusat Statistik. 2014. Horticulture Statistic. http://bps.go.id.diakses pada tanggal 12 November 2014.

Buckman, H.O and N.C. Brady. 1982. Ilmu Tanah. Diterjemahkan oleh Soegiman. Bhatara Karya Aksara. Jakarta. 788 hlmn

Brady C.N. 1992. The Nature and Properties of Soil. Mac Millan Pub. Co., New York. 621p.

Edwards, C.A. 1959. The ecology of Symphyla: part II. seasonal soil migrations.In Entomologia Experimentalis et Applicata. (2): 257-267.

Hardjowigeno, S. 2003. Ilmu Tanah. Akedemika Pressindo. Jakarta. 288 hlm

Hillel, D. 1980. Introducion to Soil Physics. Diterjemahkan oleh Rohiyanto, H. S. Dan Rahmad, H.P. Fakultas Pertanian Universitas Sriwijaya. Indralaya. $297 \mathrm{hlm}$.

Rukmana, R.1996. Nanas Budidaya dan Pascapanen. Kanisius. Yogyakarta.

Soepardi, G. 1983. Sifat dan Ciri Tanah. Departemen Ilmu-ilmu Tanah. Fakultas Pertanian IPB. Bogor. $591 \mathrm{hlm}$. 
Sandi Aji dkk: Pengaruh Sifat Fisik Tanah Terhadap Hama Simphylid Pada tanaman Nanas....

Umble, J., R. Dufour, G. Fisher, J. Fisher, J. Leap, and M. VanHorn. 2006. In P. Williams (Ed.) Symphylans: Soil Pest Management Options. ATTRA. National Sustainable Agriculture Information Service. Version 21506. Website:www.attra.ncat.org. pp. 1-16. 